\title{
PENGARUH LINGKUNGAN, MOTIVASI DAN DISIPLIN TERHADAP KINERJA KARYAWAN PADA PT. ANUGERAH ABADI BERSAMA
}

\section{(INFLUENCE OF ENVIRONMENT, MOTIVATION AND DISCIPLINE ON EMPLOYEE PERFORMANCE IN PT. ANUGERAH ABADI BERSAMA)}

Oleh:

Meribet Hutagalung ${ }^{1)}$; Yuli Triastuti' ${ }^{2)}$

Sekolah Tinggi Ilmu Ekonomi IPWI Jakarta1,2)

meribethutagalung@gmail.com ${ }^{1)}$;yulitrias@gmail.com ${ }^{2)}$

\begin{abstract}
Work environment, motivation and work discipline are three factors that are suspected to be relatively large in influencing employee performance at PT. Anugerah Abadi Bersama. Conducted research with the aim to determine the effect of the environment, motivation and discipline on employee performance at PT. Anugerah Abadi Bersama. The study was conducted at PT. Anugerah Abadi Bersama by taking 100 employees as research samples. The study was conducted quantitatively by describing research data and descriptive analysis, multiple linear regression analysis, $F$ test and test. The three main findings in accordance with the proposed hypothesis, namely: 1) The work environment partially did not significantly influence employee performance; 2) Motivation partially has a significant effect on employee performance; 3) Work discipline partially has a significant effect on employee performance at PT. Anugerah Abadi Bersama.
\end{abstract}

Keywords: Work Environment, Motivation, Work Discipline, Employee Performance.

\section{ABSTRAK}

Lingkungan kerja, motivasi dan disiplin kerja merupakan tiga faktor yang diduga relatif besar dalam memepengaruhi kinerja karyawan pada PT. Anugerah Abadi Bersama. Dilakukan penelitian dengan tujuan untuk mengetahui pengaruh lingkungan, motivasi dan disiplin terhadap kinerja karyawan pada PT. Anugerah Abadi Bersama. Penelitian dilakukan di PT. Anugerah Abadi Bersama dengan mengambil 100 karyawan sebagai sampel penelitian. Penelitian dilakukan secara kuantitatif yaitu dengan mendeskripsikan data penelitian dan analisis deskriptif, analisis regresi linier berganda, uji F dan uji t. Penelitian menghasilkan tiga temuan utama sesuai dengan hipotesis yang diajukan, yaitu: 1) Lingkungan kerja secara parsial tidak berpengaruh signifikan terhadap kinerja karyawan; 2) Motivasi secara parsial berpengaruh signifikan terhadap kinerja karyawan; 3) Disiplin kerja secara parsial berpengaruh signifikan terhadap kinerja karyawan pada PT. Anugerah Abadi Bersama.

Kata kunci: Lingkungan Kerja, Motivasi, Disiplin Kerja, Kinerja Karyawan. 


\section{PENDAHULUAN}

Perusahaan yang ingin maju tentunya berusaha meningkatkan kemampuan dan keterampilan yang dimiliki karyawannya karena hal tersebut merupakan salah satu kunci keberhasilan karyawan dalam meningkatkan kinerjanya. Kinerja karyawan dipengaruhi oleh bermacammacam variabel, beberapa diantaranya adalah variabel-variabel yang ada didalam penelitian ini, seperti lingkungan kerja, motivasi kerja dan disiplin kerja. Jika lingkungan kerja baik, motivasi kerja baik, dan disiplin kerja baik maka kinerja yang dihasilkan juga akan baik.

Lingkungan kerja yang nyaman dan kondusif, dapat membuat karyawan menyelesaikan semua pekerjaan sesuai tanggung jawab yang sudah diberikan oleh perusahaan. Oleh sebab itu lingkungan kerja sangat penting dalam perusahaan, dengan lingkungan kerja yang mendukung maka karyawan dapat bekerja secara optimal, sehingga karyawan dapat menghasilkan hasil kerja yang optimal. Hal ini dibuktikan oleh penelitian Pangesti (2017) dan Suminar dkk (2015) yang membuktikan bahwa lingkungan kerja berpengaruh signifikan terhadap kinerja karyawan.

Dalam upaya meningkatkan kinerja karyawan, tidak hanya lingkungan kerja yang harus diperhatikan oleh perusahaan, tetapi motivasi kerja juga perlu diperhatikan karena merupakan faktor yang sangat menentukan kinerja. Sutrisno (2016: 110) menyebutkan bahwa motivasi adalah sesuatu yang menimbulkan dorongan kerja.

Jadi pada dasarnya apabila perusahaan ingin meraih kinerja yang optimal sesuai dengan target yang telah di tentukan maka perusahaan haruslah memberikan motivasi pada karyawan agar karyawan mau dan rela mencurahkan tenaga dan pikiran yang dimiliki demi pekerjaan. Penelitian Saptiani (2017) dan Paramita (2014) menunjukkan bahwa motivasi berpengaruh signifikan terhadap kinerja karyawan.

Selain lingkungan kerja dan motivasi kerja untuk meningkatkan kinerja karyawan perlu juga disiplin kerja. Disiplin merupakan tindakan manajemen untuk mendorong para anggota organisasi memenuhi tuntutan berbagai ketentuan. Singodimedjo dalam Sutrisno (2011: 86) disiplin adalah sikap kesediaan dan kerelaan seseorang untuk mematuhi dan mentaati norma-norma peraturan yang berlaku di sekitarnya.

Disiplin kerja tidak hanya kepatuhan dan ketaatan terhadap peraturanperaturan yang berlaku dalam perusahaan, tetapi juga bagaimana ketegasan hukum dalam menyikapi karyawan atau anggota perusahaan yang melakukan pelanggaran terhadap peraturan dan ketentuan tersebut. Hal ini diperkuat dengan penelitian Lucky dan Nara (2018) dan Wairooy (2017) yang menunjukkan bahwa disiplin kerja signifikan terhadap kinerja karyawan.

Penelitian ini melibatkan karyawan PT. Anugerah Abadi Bersama, merupakan perusahaan yang bergerak dibidang Garmen yang memproduksi T-Shirts, Tank top, Polo shirt, Kemeja , Zip Jacket, Pants. PT. Anugerah Abadi Bersama didirikan oleh Woon Keun Yoo pada tanggal 01 Oktober 2009, Beralamat di Kampung Baru RT 003/008, Desa Wanaherang, Kecamatan Gunung Putri, Bogor, Jawa Barat.

Permasalahan-permasalahan yang muncul pada perusahaan garmen khususnya PT. Anugerah Abadi Bersama adalah hal umum yang biasa terjadi dalam keseharian proses jalannya suatu pekerjaan. Adapun permasalahan tersebut meliputi beberapa aspek pokok seperti bagaimana kesalahan pengawas dan manajemen dalam menjaga ruang dan pola 
kerja karyawan yang justru terkadang menimbulkan rasa malas dan bosan sehingga kinerja menurun. Kurangnya rasa memiliki perusahaan serta didukung oleh lemahnya wawasan serta pengetahuan pengawas dan manajemen akan bagaimana memberikan motivasi yang baik demi peningkatan rasa nyaman dan tanggung jawab serta disiplin kerja kepada karyawan adalah salah satu faktor kenapa angka turn over sangat tinggi.

\section{TUJUAN PENELITIAN}

1. Untuk mengetahui apakah terdapat pengaruh lingkungan kerja terhadap kinerja karyawan pada PT. Anugerah Abadi Bersama.

2. Untuk mengetahui apakah terdapat pengaruh motivasi kerja terhadap kinerja karyawan pada PT. Anugerah Abadi Bersama.

3. Untuk mengetahui apakah terdapat pengaruh disiplin kerja terhadap kinerja karyawan pada PT. Anugerah Abadi Bersama.

\section{TELAAH LITERATUR DAN PENGEMBANGAN HIPOTESIS Lingkungan Kerja}

Lingkungan kerja adalah suasana dimana karyawan melakukan aktivitas setiap harinya. Meskipun lingkungan kerja tidak melaksanakan proses produksi dalam suatu perusahaan, namun lingkungan kerja mempunyai pengaruh langsung terhadap para karyawan yang melaksanakan proses produksi tersebut. Menurut Siagian (2014: 56) mengemukakan bahwa lingkungan kerja adalah lingkungan dimana pegawai melakukan pekerjaannya sehari-hari.

Menurut Widodo (2015: 95) lingkungan kerja merupakan lingkungan dimana para karyawan dapat melaksanakan tugasnya sehari-hari dengan keseluruhan sarana dan prasarana kerja yang diperlukan untuk melaksanakan tugas-tugas tersebut.

Sedangkan Sedarmayanti (2012: 21) mengemukakan lingkungan kerja adalah keseluruhan alat perkakas dan bahan yang dihadapi lingkungan sekitarnya, dimana seseorang bekerja, metode kerjanya, serta pengaturan kerjanya baik sebagai perseorangan maupun sebagai kelompok.

Dari beberapa pendapat ahli diatas, maka dapat disimpulkan bahwa lingkungan kerja merupakan segala sesuatu yang ada disekitar karyawan yang berbentuk fisik ataupun psikologis, yang pada saat proses bekerja setiap hari baik perseorangan maupun kelompok dapat meningkatkan semangat dan kinerja karyawan.pekerjaannya sehari-hari.

\section{Motivasi}

Motivasi berasal dari kata latin movere yang berarti dorongan, daya penggerak atau kekuatan yang menyebabkan suatu tindakan atau perbuatan. Kata movere, dalam bahasa inggris sering disamakan dengan motivation yang berarti pemberian motif atau hal yang menimbulkan dorongan.

Menurut Hasibuan (2013: 143) mengatakan bahwa motivasi kerja adalah pemberian daya penggerak yang menciptakan kegairahan kerja seseorang agar mereka mau bekerja sama, bekerja efektif, dan terintegrasi dengan segala daya upayanya untuk mencapai kepuasan.

Rivai (2011: 455) adalah motivasi kerja adalah serangkaian sikap dan nilai-nilai yang mempengaruhi individu untuk mencapai hal yang spesifik sesuai dengan tujuan individu.

Sedangkan menurut Berelson dan Gary dalam Suwatno dan Priansa (2011: 147), menyatakan bahwa motivasi sebagai keadaan kejiwaan dan sikap mental manusia yang memberikan energi, 
mendorong kegiatan/gerakan dan mengarah atau menyalurkan perilaku ke arah mencapai kebutuhan yang memberi kepuasan atau mengurangi ketidak seimbangan.

Dari beberapa pengertian diatas dapat disimpulkan bahwa motivasi adalah suatu dorongan yang menggerakkan seseorang dan memberikan kekuatan yang mengarah kepada pencapaian kebutuhan, memberi kepuasan ataupun mengurangi ketidak seimbangan dalam mencapai tujuan yang telah ditetapkan perusahaan.

\section{Disiplin Kerja}

Disiplin berasal dari bahasa Latin discipline yang berarti latihan atau pendidikan kesopanan dan kerohanian serta pengembangan tabiat. Disiplin merupakan suatu kekuatan yang berkembang di dalam tubuh pekerja sendiri yang menyebabkan dia dapat menyesuaikan diri dengan sukarela kepada keputusan-keputusan, peraturanperaturan, dan nilai-nilai tinggi dari pekerjaan dan tingkah laku.

Menurut Sutrisno (2016: 89) menyatakan bahwa disiplin adalah perilaku seseorang yang sesuai dengan peraturan, prosedur kerja yang ada atau disiplin adalah sikap, tingkah laku, dan perbuatan yang sesuai dengan peraturan dari organisasi baik tertulis maupun tidak tertulis.

Hasibuan dalam Barnawi dan Muhammad (2012: 112) adalah disiplin kerja adalah kemampuan kerja seseorang untuk secara teratur, tekun, terus-menerus, dan bekerja sesuai dengan aturan-aturan yang berlaku dengan tidak melanggar aturan-aturan yang sudah ditetapkan.

Rivai (2011:825) menyatakan bahwa disiplin kerja adalah suatu alat yang dipergunakan para manajer untuk berkomunikasi dengan pegawai agar mereka bersedia untuk mengubah suatu perilaku serta sebagai suatu upaya untuk meningkatkan kesadaran dan kesediaan seorang dalam memenuhi segala peraturan perusahaan.

Dari pengertian para ahli di atas dapat disimpulkan bahwa disiplin kerja adalah suatu sikap menghormati, menghargai, patuh dan taat terhadap peraturanperaturan yang berlaku baik yang tertulis maupun yang tidak tertulis dalam perusahaan yang harus dipatuhi oleh setiap karyawan tanpa terkecuali.

\section{Kinerja Karyawan}

Kinerja dapat diketahui hanya jika individu atau kelompok individu tersebut memiliki kriteria keberhasilan yang telah ditetapkan. Kriteria keberhasilan ini berupa tujuan-tujuan atau target-target tertentu yang hendak dicapai. Tanpa adanya tujuan serta target, kinerja seseorang atau organisasi tidak dapat diketahui karena tidak ada tolak ukurnya.

Bastian (2010: 2) kinerja dapat diartikan sebagai gambaran mengenai tingkat pencapaian pelaksanaan suatu kegiatan atau program, atau kebijakan dalam mewujudkan sasaran, tujuan, misi dan visi organisasi yang tertuang dalam rencana strategi suatu organisasi.

Mangkunegara (2014: 9) berpendapat bahwa kinerja karyawan adalah hasil kerja secara kualitas dan kuantitas yang dicapai oleh seseorang karyawan dalam melaksanakan tugasnya sesuai dengan tanggung jawab yang diberikan kepadanya.

Sedangkan menurut Rivai (2010) kinerja merupakan perilaku nyata yang ditampilkan setiap orang sebagai prestasi kerja yang dihasilkan oleh karyawan sesuai dengan perannya dalam perusahaan. Ukuran kinerja dapat dilihat dari sisi jumlah dan mutu tertentu sesuai dengan standar organisasi perusahaan. 
Dari beberapa definisi di atas, dapat disimpulkan bahwa kinerja adalah hasil kerja seseorang atau sekelompok orang dalam suatu organisasi atau perusahaan secara kualitas dan kuantitas pada periode tertentu yang merefleksikan seberapa baik seseorang atau kelompok tersebut memenuhi persyaratan sebuah pekerjaan dalam usaha pencapaian tujuan organisasi atau perusahaan. Dengan meningkatkan kinerja karyawan maka akan menimbulkan dampak positif terhadap produktifitas perusahaan, keadaan ini merupakan suatu aktivitas perusahaan yang akan ditingkatkan agar dapat menciptakan iklim organisasi yang dapat menghasilkan

\section{Kerangka Pemikiran}

Kerangka pemikiran berisi tentang penjelasan hubungan antara variabel Independent (lingkungan kerja, motivasi kerja dan disiplin kerja) dan variabel dependent (kinerja pegawai).

Gambar 1

Kerangka Pemikiran

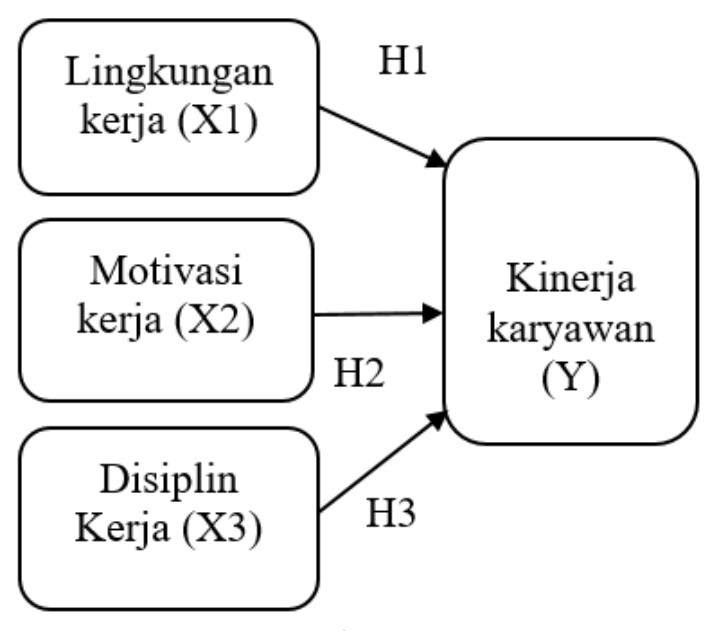

\section{Hipotesis}

H1: Lingkungan kerja berpengaruh terhadap kinerja karyawan.

$\mathrm{H} 2$ : Motivasi kerja berpengaruh terhadap kinerja karyawan.
H3: Disiplin kerja berpengaruh terhadap kinerja karyawan.

\section{METODE PENELITIAN \\ Jenis Penelitian}

Penelitian ini merupakan penelitian deskriptif dengan menggunakan pendekatan kuantitatif. Menurut Mulyanto (2010: 23) penelitian kuantitatif merupakan suatu pendekatan penelitian yang bersifat obyektif, menekankan pada pengujian teori-teori melalui pengukuran variabelvariabel penelitian dengan angka dan melakukan analisis data dengan metode pengujian statistik.

\section{Sampel Penelitian}

Penelitian dilakukan di PT. Anugerah Abadi Bersama dengan mengambil 100 karyawan sebagai sampel penelitian yang dihitung menggunakan rumus Slovin dari total populasi 1369 karyawan pada margin error $10 \%$.

\section{Desain Penelitian}

Variabel yang digunakan dalam penelitian ini adalah:

1. Variabel Bebas (independen)

Variabel yang mempengaruhi atau yang menjadi sebab perubahannya atau timbulnya variabel dependen (terikat). Variabel dependen dalam penelitian ini adalah lingkungan kerja (X1), motivasi kerja (X2) dan disiplin kerja (X3).

2. Variabel Terikat (dependen)

Merupakan variabel yang dipengaruhi atau yang menjadi akibat, karena adanya variabel bebas. Variabel dependen dalam penelitian ini adalah kinerja karyawan.

\section{Operasionalisasi Variabel}

Operasionalisasi variabel penelitian dapat dikemukakan sebagai berikut: 
Table 1

Variabel Lingkungan Kerja (X1)

\begin{tabular}{|c|c|c|}
\hline Dimensi & Indikator & Item \\
\hline $\begin{array}{l}\text { Lingkun } \\
\text { gan kerja } \\
\text { fisik }\end{array}$ & 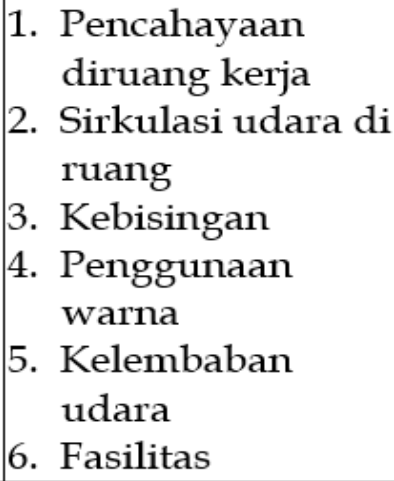 & $\begin{array}{l}2 \\
3 \\
4 \\
5 \\
6\end{array}$ \\
\hline $\begin{array}{l}\text { Lingkun } \\
\text { gan kerja } \\
\text { non fisik }\end{array}$ & 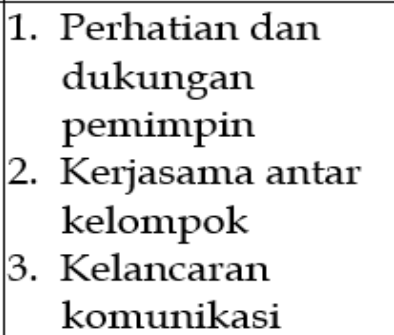 & $\begin{array}{l}8 \\
9\end{array}$ \\
\hline
\end{tabular}

Sumber: Schultz (2014: 56).

Table 2

Variabel Motivasi kerja (X2)

\begin{tabular}{|c|c|c|}
\hline Dimensi & Indikator & Item \\
\hline $\begin{array}{l}\text { Kebutuh } \\
\text { an akan } \\
\text { prestasi }\end{array}$ & $\begin{array}{l}\text { 1. } \text { Menunjukkan } \\
\text { prestasi. } \\
\text { 2. Mengikuti diklat } \\
\text { 3. } \text { Bangga menjadi } \\
\text { acuan sejawat. }\end{array}$ & $\begin{array}{l}1 \\
2 \\
3\end{array}$ \\
\hline $\begin{array}{l}\text { Kebutuh } \\
\text { an akan } \\
\text { kekuasaa } \\
\text { n }\end{array}$ & $\begin{aligned} & \text { 1. } \text { Kewenangan dan } \\
& \text { tanggung jawab } \\
& \text { 2. } \begin{array}{l}\text { Menyelesaikan } \\
\text { pekerjaan dengan }\end{array} \\
& \text { metode sendiri. } \\
& \text { 3. } \begin{array}{l}\text { Mendapatkan } \\
\text { kedudukan }\end{array}\end{aligned}$ & $\begin{array}{l}4 \\
5\end{array}$ \\
\hline $\begin{array}{l}\text { Kebutuh } \\
\text { an akan } \\
\text { afiliasi }\end{array}$ & 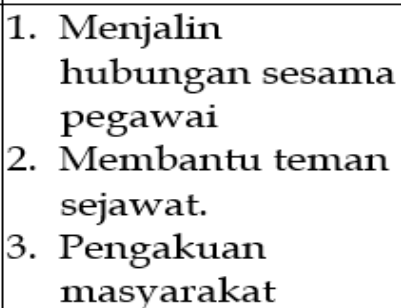 & $\begin{array}{l}8 \\
9\end{array}$ \\
\hline
\end{tabular}

Sumber: Hasibuan (2013: 143)/
Table 3

Variabel Disiplin Kerja (X3)

\begin{tabular}{|c|c|c|}
\hline Dimensi & Indikator & Item \\
\hline $\begin{array}{l}\text { Tujuan } \\
\text { kemamp } \\
\text { uan }\end{array}$ & $\begin{array}{l}\text { 1. Kehadiran tepat } \\
\text { waktu } \\
\text { 2. Intensitas } \\
\text { kehadiran tinggi }\end{array}$ & 2 \\
\hline $\begin{array}{l}\text { Ketaatan } \\
\text { pada } \\
\text { standar } \\
\text { kerja }\end{array}$ & $\begin{array}{l}\text { 1. } \text { Memiliki rasa } \\
\text { tanggung jawab } \\
\text { 2. Sesuai fungsi dan } \\
\text { tugasnya. } \\
\text { 3. } \\
\text { Bekerja sesuai jam } \\
\text { kerja. }\end{array}$ & $\begin{array}{l}4 \\
5\end{array}$ \\
\hline $\begin{array}{l}\text { Ketaatan } \\
\text { pada } \\
\text { Peratura } \\
\text { n Kerja }\end{array}$ & $\begin{array}{l}\text { 1. } \text { Pemahaman } \\
\text { peraturan kerja. } \\
\text { 2. } \text { Bekerja sesuai } \\
\text { peraturan kerja. }\end{array}$ & 6 \\
\hline $\begin{array}{l}\text { Etika } \\
\text { Kerja }\end{array}$ & $\begin{array}{l}\text { 1. Memiliki sikap } \\
\text { dan perilaku baik }\end{array}$ & 8 \\
\hline
\end{tabular}

Sumber: Rivai (2011: 825).

Table 4

Variabel Kinerja Karyawan (Y)

\begin{tabular}{|c|c|c|}
\hline Dimensi & Indikator & Item \\
\hline $\begin{array}{l}\text { Kuanti- } \\
\text { tas kerja }\end{array}$ & $\begin{array}{l}\text { 1. Kecepatan } \\
\text { 2. Kemampuan }\end{array}$ & $\begin{array}{l}1 \\
2\end{array}$ \\
\hline $\begin{array}{l}\text { Kualitas } \\
\text { dari hasil }\end{array}$ & $\begin{array}{l}\text { 1. Kerapihan } \\
\text { 2. Ketelitian } \\
\text { 3. Hasil kerja sesuai } \\
\text { perintah }\end{array}$ & $\begin{array}{l}3 \\
4 \\
5\end{array}$ \\
\hline $\begin{array}{l}\text { Kerja } \\
\text { sama }\end{array}$ & $\begin{array}{l}\text { 1. Jalinan kerja sama } \\
\text { 2. Kekompakan }\end{array}$ & $\begin{array}{l}6 \\
7\end{array}$ \\
\hline $\begin{array}{l}\text { Tang- } \\
\text { gung } \\
\text { jawab }\end{array}$ & $\begin{array}{l}\text { 1. Tanggung jawab } \\
\text { atas hasil kerja } \\
\text { 2. Mengambil } \\
\text { keputusan }\end{array}$ & 8 \\
\hline Inisiatif & $\begin{array}{l}\text { 1. Kemampuan } \\
\text { inisiatif }\end{array}$ & 10 \\
\hline
\end{tabular}




\section{Metode Analisis}

Analisis data menggunakan software SPSS Versi 20 dengan tahap yaitu: Uji validitas dan Reliabilitas, Analisis regresi linier ganda yaitu: Prasyarat Analisis, Uji model dan Uji hipotesis.

\section{Uji Validitas Reliabilitas}

Suatu item pertanyaan dikatakan valid jika nilai rhitung > rtabel, dan signifikan < 0.05. Uji statistik Cronbach Alpha (a) suatu variabel dikatakan reliabel jika memiliki nilai Cronbach Alpha > 0,70 Nunnally dikutip oleh Ghozali, (2013).

\section{Analisis Regresi Ganda}

Analisis ini digunakan untuk menunjukkan pengaruh variabel bebas terhadap variabel terikat yaitu melalui:

1) Prasyarat Analisis

Normalitas dapat dideteksi dengan melihat penyebaran data (titik) pada sumbu diagonal dari grafik atau dengan melihat histogram dari residualnya (Ghozali, 2013).

2) Uji Model

Analisis Koefisien Determinasi dimana nilai koefisien determinasi adalah antara nol dan satu. Uji statsistik f pada dasarnya menunjukkan apakah semua variabel independen atau bebas yang dimasukkan dalam model mempunyai pengaruh secara bersama-sama terhadap variabel dependen/terikat, Ghozali (2013).

3) Pengujian Hipotesis

Model persamaan regresi linier ganda $\mathrm{Y}=\mathrm{a}+\mathrm{b} 1 \mathrm{X} 1+\mathrm{b} 2 \mathrm{X} 2+\mathrm{b} 3 \mathrm{X} 3$. Untuk menguji variabel yang berpengaruh antara X1, X2, X3 terhadap $\mathrm{Y}$ secara individual (parsial) maka digunakan uji t.

\section{HASIL PENELITIAN DAN \\ PEMBAHASAN}

Uji Validitas dan Uji Reliabilitas

Hasil uji validitas dan reliabilitas adalah sebagai berikut:

Uji Validitas dan Reliabilitas Lingkungan Kerja (X1)

Berdasarkan hasil perhitungan uji validitas variabel lingkungan kerja (X1) dengan 9 item pertanyaan, maka didapat hasil seluruh pertanyaan untuk variabel lingkungan kerja (X1) memiliki status valid, karena rhitung (Corrected Item-Total Correlation) > rtabel sebesar 0,197.

Sedangkan hasil uji reliabilitas menunjukkan bahwa nilai cronbach's alpha atas variabel lingkungan kerja (X1) sebesar 0,855. Sehingga dapat disimpulkan bahwa pertanyaan dalam kuesioner dinyatakan reliabel, karena mempunyai nilai cronbach's alpha $>0,70$.

\section{Uji Validitas dan Reliabilitas Motivasi Kerja (X2)}

Berdasarkan hasil perhitungan uji validitas variabel motivasi kerja (X2) dengan 9 item pertanyaan, maka didapat hasil seluruh pertanyaan untuk variabel motivasi kerja (X2) memiliki status valid, karena rhitung (Corrected Item-Total Correlation) > rtabel sebesar 0,197.

Sedangkan hasil uji reliabilitas menunjukkan bahwa nilai cronbach's alpha atas variabel motivasi kerja (X2) sebesar 0,863. Sehingga dapat disimpulkan bahwa pertanyaan dalam kuesioner dinyatakan reliabel, karena mempunyai nilai cronbach's alpha $>0,70$.

\section{Uji Validitas dan Reliabilitas Disiplin Kerja (X3)}

Berdasarkan hasil perhitungan uji validitas variabel disiplin kerja (X3) dengan 10 item pertanyaan, maka didapat hasil seluruh pertanyaan untuk variabel disiplin kerja (X3) memiliki status valid, 
karena rhitung (Corrected Item-Total Correlation) > rtabel sebesar 0,197.

Sedangkan hasil uji reliabilitas menunjukkan bahwa nilai cronbach's alpha atas variabel disiplin kerja (X3) sebesar 0,879. Sehingga dapat disimpulkan bahwa pertanyaan dalam kuesioner dinyatakan reliabel, karena mempunyai nilai cronbach's alpha $>0,70$.

\section{Uji Validitas dan Reliabilitas Kinerja Karyawan (Y)}

Berdasarkan hasil perhitungan uji validitas variabel kinerja karyawan (Y) dengan 10 item pertanyaan, maka didapat hasil seluruh pertanyaan untuk variabel kinerja karyawan (Y) memiliki status valid, karena rhitung (Corrected Item-Total Correlation) > rtabel sebesar 0,197.

Sedangkan hasil uji reliabilitas menunjukkan bahwa nilai cronbach's alpha atas variabel kinerja karyawan (Y) sebesar 0,850. Sehingga dapat disimpulkan bahwa pertanyaan dalam kuesioner dinyatakan reliabel, karena mempunyai nilai cronbach's alpha $>0,70$.

\section{Uji Model}

\section{Koefisien Determinasi}

Koefisien determinasi ini digunakan untuk mengetahui seberapa besar pengaaruh variabel-variabel bebas (independen) dapat menjelaskan variasi variabel terikatnya (dependen).

Tabel 5

Koefisien Determinasi

Model Summary

\begin{tabular}{l|c|r|r|c|}
\hline Model & R & R Square & $\begin{array}{c}\text { Adjusted R } \\
\text { Square }\end{array}$ & $\begin{array}{c}\text { Std. Error of } \\
\text { the Estimate }\end{array}$ \\
\hline 1 & $.741^{\mathrm{a}}$ & .550 & .536 & 2.459 \\
\hline
\end{tabular}

Sumber: data penelitian diolah, 2019
Dari tabel 1 hasil koefisien determinasi dilihat dari R Square, yaitu sebesar 0.550. hal ini berarti 55\% kinerja karyawan dapat dijelaskan oleh variabel lingkungan kerja, motivasi dan disiplin kerja. Sedangkan sisanya $45 \%$ variabel kinerja karyawan dapat dijelaskan oleh variabel-variabel lainnya yang tidak diteliti oleh penelitian ini.

\section{ujif}

Berdasarkan analisis dengan menggunakan program SPSS maka diperoleh hasil uji f sebagai berikut:

Tabel 6

Hasil Uji F

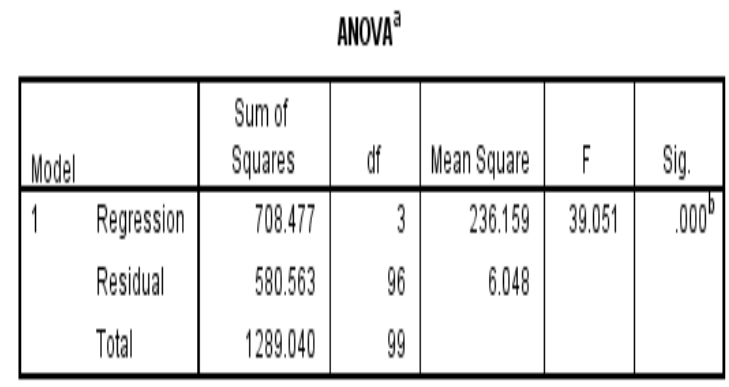

a. Dependent Variable: Kineria Kavyawan

b. Predictors:' (Constant), Disiplin Keria, Lingkunngan Kerja, Motivasi Kerija

Sumber: data penelitian diolah, 2019

Dari tabel diatas hasil perhitungan statistik menunjukkan nilai fhitung sebesar 39.051. Setelah itu dibandingkan dengan nilai ftabel sebesar 2.70 dengan signifikansi $0.05(5 \%)$. Jadi dapat disimpulkan fhitung > ftabel $(39.051>2.70)$ dengan sig sebesar $0.000<0.05$. Hal ini berarti bahwa Ho ditolak dan Ha diterima artinya lingkungan, motivasi dan disiplin kerja mempunyai pengaruh secara simultan terhadap kinerja karyawan pada PT. Anugerah Abadi Bersama.

\section{Analisis Regresi Linier Berganda}

Adapun hasil olahan data dengan menggunakan program SPSS 20 dapat dirangkum melalui tabel berikut: 
Tabel 7

Hasil Uji Regresi Linier Ganda

Coefficients ${ }^{\mathrm{a}}$

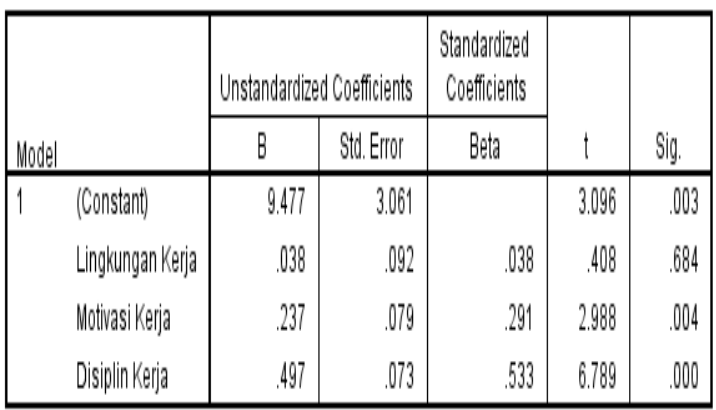

a. Dependent Variable: Kinerija Kavawan

Dari tabel 3 dapat diketahui persamaan regresi linear berganda sebagai berikut: $\mathrm{Y}=9.477+0.038 \mathrm{X} 1+0.237 \mathrm{X} 2+$ $0.497 X 3$. Persamaan diatas dapat dijelaskan sebagai berikut:

- $\quad$ a =9.477: hal ini menunjukkan bahwa jika lingkungan, motivasi dan disiplin kerja memiliki nilai sama dengan nol, maka kinerja karyawan akan meningkat sebesar 9.477 .

- $\quad$ b1 = 0.038: hal ini menunjukkan bahwa jika variabel lingkungan kerja meningkat 1, maka kinerja karyawan akan meningkat sebesar 0.038 .

- $\quad$ b2 =0.237: hal ini menunjukkan bahwa jika motivasi kerja meningkat 1 maka kinerja karyawan akan meningkat sebesar 0.237.

- $\quad$ b3 = 0.497: hal ini menunjukkan bahwa jika variabel disiplin kerja meningkat 1, maka kinerja karyawan (Y) meningkat sebesar 0.497 .

\section{Pengujian Hipotesis}

Uji $t$ dilakukan untuk mengetahui pengaruh masing-masing atau secara parsial variabel bebas (independen) terhadap variabel terikat (dependen).
Tabel 8

Hasil Uji t

Coefficients ${ }^{\mathrm{a}}$

\begin{tabular}{|c|c|c|c|c|c|c|}
\hline \multirow[b]{2}{*}{ Model } & & \multicolumn{2}{|c|}{ Unstandardized Coefficients } & \multirow{2}{*}{$\begin{array}{c}\text { Standardized } \\
\text { Coefficients } \\
\text { Beta }\end{array}$} & \multirow[b]{2}{*}{1} & \multirow[b]{2}{*}{ Sig. } \\
\hline & & $B$ & Stol Error & & & \\
\hline 1 & (Constant) & 9.477 & 3.061 & & 3.096 & .003 \\
\hline & Lingkungan Kerja & .038 & .092 & .038 & .408 & .684 \\
\hline & Motivasi Keria & .237 & .079 & .291 & 2.988 & .004 \\
\hline & Disiplin Keria & .497 & .073 & .533 & 6.789 & .000 \\
\hline
\end{tabular}

a. Dependent Variable: Kinerija Kanawan

Berdasarkan tabel di atas pengujian hipotesis dalam penelitian ini adalah sebagai berikut:

- Pengujian Hipotesis Pertama (H1)

Dari hasil perhitungan yang diperoleh thitung untuk X1 sebesar 0.408 dengan sig 0.684 dengan menggunakan taraf signifikansi $5 \%$ diperoleh nilai probabilitas lebih besar dari 0.05, berarti Ha ditolak dan Ho diterima. Dengan demikian berarti hipotesis pertama (H1) ditolak.

- $\quad$ Pengujian Hipotesis Kedua (H2)

Dari hasil perhitungan yang diperoleh thitung untuk X2 sebesar 2.988 dengan sig 0.004 dengan menggunakan taraf signifikansi 5\% diperoleh nilai probabilitas lebih kecil dari 0.05, berarti Ha diterima dan Ho ditolak. Dengan demikian berarti hipotesis kedua (H2) diterima.

- $\quad$ Pengujian Hipotesis Ketiga (H3)

Dari hasil perhitungan yang diperoleh thitung untuk X3 sebesar 6.789 dengan sig 0.000 dengan menggunakan taraf signifikansi $5 \%$ diperoleh nilai probabilitas lebih kecil dari 0.05, berarti Ha diterima dan Ho ditolak. Dengan demikian berarti hipotesis ketiga (H3) diterima. 
Pembahasan Penelitian

Pengaruh Lingkungan Kerja terhadap Kinerja Karyawan

Hasil hipotesis menunjukkan bahwa variabel lingkungan kerja tidak berpengaruh signifikan terhadap kinerja karyawan pada PT. Anugerah Abadi Bersama.

Hasil penelitian ini tidak sesuai dengan penelitian terdahulu yang dilakukan oleh penelitian Pangesti (2017) yang melakukan penelitian tentang pengaruh lingkungan kerja, keselamatan kerja dan kompensasi terhadap kinerja karyawan pada konveksi Bagas Jaya Kabupaten Tulungagung, dari hasil penelitian menunjukkan bahwa lingkungan kerja memiliki pengaruh yang signifikan terhadap kinerja karyawan. Penelitian lain yang berkaitan dengan lingkungan kerja dilakukan oleh Suminar dkk (2015) yang meneliti tentang pengaruh gaya kepemimpinan dan lingkungan kerja terhadap kinerja karyawan pada PT. Essentra Indonesia, Sidoarjo, dengan hasil penelitian menyatakan secara simultan dan parsial gaya kepemimpinan dan lingkungan kerja berpengaruh signifikan terhadap kinerja karyawan.

\section{Pengaruh Motivasi Kerja terhadap Kinerja Perusahaan}

Hasil hipotesis menunjukkan bahwa variabel motivasi (X2) berpengaruh signifikan terhadap kinerja karyawan $(\mathrm{Y})$ pada PT. Anugerah Abadi Bersama. Maka semakin baik motivasi kerja maka semakin besar pengaruhnya terhadap kinerja karyawan.

Hasil penelitian ini sesuai dengan penelitian terdahulu yang dilakukan oleh Penelitian Saptiani (2017) yaitu pengaruh motivasi dan pengalaman kerja terhadap kinerja pegawai pada Badan Kepegawaian Daerah Kota Medan, dari hasil penelitian menunjukkan motivasi dan pengalaman kerja berpengaruh positif dan signifikan terhadap kinerja pegawai. Dan diikuti dengan penelitian Paramita (2014) yaitu pengaruh motivasi dan budaya organisasi terhadap kinerja karyawan pada PT. Centrepark Citra Corpora Area Solo Grand Mall, dari hasil penelitian menunjukkan bahwa motivasi dan budaya organisasi berpengaruh signifikan terhadap kinerja karyawan.

Saran untuk responden agar lebih meningkatkan motivasi dalam bekerja yaitu dengan menjalin hubungan yang lebih harmonis sesama karyawan dan atasan, dan saling membantu teman sejawat dalam bekerja.

\section{Pengaruh Disiplin Kerja terhadap Kinerja Karyawan}

Hasil hipotesis menunjukkan bahwa variabel disiplin kerja berpengaruh signifikan terhadap kinerja karyawan pada PT. Anugerah Abadi Bersama. Maka semakin baik disiplin kerja maka semakin besar pengaruhnya terhadap kinerja karyawan.

Hasil penelitian ini sesuai dengan penelitian terdahulu yang dilakukan oleh penelitian Lucky dan Nara (2018) yang meneliti tentang pengaruh pelatihan, disiplin dan pengembangan karir terhadap kinerja karyawan pada PT. Gardautama, hasil penelitian menyimpulkan bahwa pelatihan, disiplin dan pengembangan karir berpengaruh signifikan terhadap kinerja karyawan. Penelitian Wairooy (2017) yaitu pengaruh disiplin kerja dan kompensasi terhadap kinerja karyawan PT. Pertamina (Persero) Tbk, bahwa hasil penelitian menujukkan disiplin kerja dan kompensasi secara simultan dan parsial berpengaruh positif dan signifikan terhadap kinerja karyawan.

Saran untuk responden agar lebih meningkatkan disiplin dalam bekerja yaitu dengan hadir tepat waktu, lebih 
bertanggung jawab, menjaga dan merawat peralatan kerja dan menaati semua peraturan yang ada di perusahaan.

\section{KESIMPULAN}

1. Lingkungan kerja secara parsial tidak berpengaruh terhadap kinerja karyawan pada PT. Anugerah Abadi Bersama.

2. Motivasi kerja secara parsial berpengaruh positif dan signifikan terhadap kinerja karyawan pada PT. Anugerah Abadi Bersama sebesar 0.237 , artinya semakin baik motivasi kerja maka akan meningkatkkan kinerja karyawan.

3. Disiplin kerja secara parsial berpengaruh positif dan signifikan terhadap kinerja karyawan PT. Anugerah Abadi Bersama sebesar 0.497, artinya semakin baik disiplin kerja maka akan meningkatkan kinerja karyawan.

\section{SARAN}

1. PT. Anugerah Abadi Bersama lebih meningkatkan motivasi dan disiplin kerja agar kinerja karyawan menjadi lebih baik lagi.

2. Untuk penelitian selanjutnya peneliti memperluas sampel agar hasil penelitian bisa tergeneralisasi.

\section{DAFTAR PUSTAKA}

Barnawi. \& Muhammad Arifin. (2012). Etika dan Profesi Kependidikan. Jakarta: Ar-Ruzz Media.

Bastian, Indra. (2010). Akuntansi Sektor Publik: Suatu Pengantar. Jakarta: Selemba Empat.

Ghozali, Imam. (2013). Aplikasi Analisis Multivariate dengan Program IBM SPSS 21 Update PLS Regresi.
Semarang: Badan Penerbit Universitas Diponegoro.

Hasibuan, Malayu. (2013). Manajemen Sumber Daya Manusia. Cetakan Ke17. Jakarta: PT. Bumi Aksara.

Lucky, M \& Rosmadi, A. (2018). Pengaruh pelatihan, disiplin, dan pengembangan karir terhadap kinerja karyawan outsourcing PT. Gardautama. Jurnal JBMI Vol. 14 No. 3 Februari 2018.

Mulyanto, H. dan Wulandari, A. (2010). Penelitian Metode Dan Analisis. Semarang: CV. Agung.

Pangesti, K. (2017). Pengaruh lingkungan kerja, keselamatan kerja, dan kompensasi terhadap kinerja karyawan Konveksi Bagas Jaya Kabupaten Tulungagung. Jurnal Simki-Economic Vol. 01 No. 09 Tahun 2017 ISSN : BBBB-BBBB.

Paramita, R. (2014). Pengaruh motivasi dan budaya organisasi terhadap kinerja karyawan (Studi Kasus pada PT. Centrepark Citra Corpora Area Solo Grand Mall). Skripsi. Program studi akuntansi fakultas ekonomi dan bisnis Universitas Muhammadiyah Surakarta.

Rivai, Veithzal. (2011). Manajemen Sumber Daya Manusia untuk Perusahaan: dari Teori Praktik. Jakarta: Raja Grapindo Persada.

Saptiani, Y. (2017). Pengaruh motivasi dan pengalaman kerja terhadap kinerja pegawai pada Badan Kepegawaian Daerah Kota Medan. Skripsi. Progam studi manajemen fakultas ekonomi dan bisnis Universitas Medan Area.

Sedarmayanti. (2012). Manajemen dan Komponen Terkait Lainnya. Bandung: PT. Rafika Aditama.

Siagian, Sondang. P. (2014). Manajemen Sumber Daya Manusia. Jakarta: Bumi Aksara.

Singodimedjo dalam Edy, Sutrisno. (2011). Manajemen Sumber Daya Manusia. Jakarta: Prenada Media Group.

Suminar, C.A. Mukjam, D.M \& Ruhana, I. (2015). Pengaruh gaya kepemimpinan dan lingkungan kerja terhadap kinerja (Studi Kasus pada 
Karyawan Bagian Produksi PT Essentra Indonesia, Sidoarjo). Jurnal. Administrasi Bisnis (JAB) Vol. 26 No. 2 September 2015.

Sutrisno, Edy. (2016). Manajemen Sumber Daya Manusia. Cetakan Ke-8. Jakarta: Prenada Media Group.

Suwatno. \& Priansa, Donni Juni. (2013). Manajemen SDM dalam Organisasi Publik dan Bisnis. Bandung: Alfabeta.

Wairooy, A. (2017). Pengaruh disiplin kerja dan kompensasi terhadap kinerja karyawan pada PT. Pertamina (Persero), Tbk. Pemasaran Region VII Makassar. Jurnal Administrare: Jurnal pemikiran ilmiah dan pendidikan administrasi perkantoran, Vol. 4, No. $1,2017$.

Widodo, S. E. (2015). Manajemen Pengembangan Sumber Daya Manusia. Yogyakarta: Pustaka Pelajar. 